\title{
A Comparative Analysis of the Theological Polemics of Muslim Brotherhood and Salafiyyah ${ }^{1}$
}

\author{
AHMED NAFIU ARIKEWUYO²
}

\begin{abstract}
The experience of the Muslim Ummah in the 19th and 20th centuries has given rise to various revivalist thoughts aimed at reclaiming the lost glory of Islam and returning Muslims to their right position. The Muslim Brotherhood current Salafiyyah groups represent the largest revivalist trend in current time. Despite having the common mission of revitalizing the Ummah, the two trends are always at loggerhead over pressing issues of Islam. Hence, the research focuses on theological polemics as case study for the multitudinous contention between the two trends. Library research methodology was adopted. Findings of the research show that both trends share common fundamental creeds and that the popular theological dichotomy between them is due to various factors namely: the degree of priority attached to creeds, attitude towards equivocal matters of creed such as anthropomorphic status of Allah and lastly theologizing matters which are juristic. The research recommends the needs for the Salafiyyah group to focus on theological training rather than the traditionally theological polemics which was a product of refutation against the evolving heretic sects that are ideologically not existing today.
\end{abstract}

Keywords: Islamic revivalism, Islamic theology, Islamism, Muslim Brotherhood, Salafiyyah

The Muslim Brotherhood and Salafiyyah group both represent the largest revivalist trend in the current time. Addressing the mournful state of the Ummah is their common mission. Hence, the two trends have become the major platform for Muslims with revivalist aspiration in current time. It is worrying that despite the uniform mission and often the common source adopted by the two revivalist groups, they remain one of the most hostile and rival religious groups in recent time. Their hostility emanates from different approach adopted by each trend towards a large number of religious discourses. Notable religious discourses where the two groups have offered antithetical approach are theological matters, applying the comprehensiveness of Islam to modern world, concept and condemnation of Bid'ah, the concept of Jihad, attitude towards Islamic heritage, Islamic Mysticism, political reforms and participation, Caliphasy, relation with non-Muslims and approach to controversial matters of religion.

Against this backdrop, this research intends to compare the thought of the two groups on theological discourses. The relevance of the comparative analysis is to measure the virility of the existing discrepancy in the theological thought of the two groups. Furthermore, the analysis will

\footnotetext{
${ }^{1}$ Part of this article has been published in Journal of Arts, Science \& Commerce 9(4): 77-84, (2018).

${ }^{2}$ Ahmed Nafiu Arikewuyo, M.A., researcher at Centre of Islamic Heritage and Community Development, alHikmah State University, Adewole Estate, Adeta Road, ILORIN, Kwara State, Nigeria, email: abuamina20@gmail.com.
}

https://doi.org/10.24035/ijit.15.2019.002 
assist in identifying what best represents the teachings of Islam between the theological thoughts of the two groups.

\section{Historical Development of Salafiyyah}

The concept of Salafiyyah is rooted from the word: "Salaf". According to the various Arabic Dictionaries, Salaf means: Past, ancient and predecessor (Ibn Manzur 2007). A survey of the usage of the word in the Quran shows that it is used eight times in seven chapters with the literary meanings of past and preceding action. (See Q2:275, Q4:22, Q4:23, Q5:95, Q78:38, Q10:30, Q69:24 and Q43:56). Also, the word was used by the Prophet prominently in his communication with his daughter, Fatimah, when he said: "And I am to you a good predecessor" (Muslim 2008, no. 2450).

From the usage of the Quran and Prophetic tradition, it is obvious that the technical meaning of the word was not intended. Hence, Salaf, technically means the Companions of Prophet Muhammad and all those who followed their footstep. (Bakru 2012: 111). Salafiyyah is therefore the emulation of methodological and ideological tracks of the companions of the Prophet and of the ancient traditional scholars of Islam who also emulated the companions in their creeds (Hilali 2013: 37).

The inevitability and necessity of adopting Salafiyyah approach in practicing Islam was premised on the verses of the Quran that testify to the honesty and piety of the Companions of Prophet Muhammad and that of those who followed their footstep; various prophetic traditions that stress the priority and preference given by the divine to the methodology and creeds of Salaf, and that also command the subsequent Muslims to follow their track in controversial time and also premised on the texts and contents of the works produced by the classical Imams who have lived in the second, third and fourth centuries of Islam in which attacks were launched on the contrary creeds to the aforementioned. The verses of the Quran that testify to the piety and status of the Companions include: Q48:18, Q48:29, Q9:117, Q59:8 and Q8:74.

The foregoing verses have been used by the Salafi adherents to establish the superiority and preference of the method followed by the Sahabah in professing Islam. This is based on the fact that Allah as shown from the quoted verses has sanctioned their practice and behaviour (Bakru 2012: 206).

The concept of Salafiyyah is also premised on the prophetic tradition narrated by 'Abdullahi bn Mas'ud who said: "the Apostle of Allah was asked about the best set of people? The Apostle replied: "My generation, followed by those who followed them and those who also followed their followers". (Bukhari 2007: no. 2533). Also, 'Irbad bn Sariyah narrates that the Prophet was reported to have said: "Anyone of you who will live behind me shall witness serious controversy. Hence, (in order to spare yourself of its detriment), stick to my path and the path of the guided Khulafa' after me. Hold on it seriously (Tirmidhi 2004: 266).

In obedience to the aforementioned texts in the Quran and Sunnah, there arose in the Muslim Ummah right from the beginning of Islamic history a trend that had been using the creeds and actions of the Companions as criteria for accepting and rejecting religious practices. It is acknowledged that from the onset, those sets of people were not being referred to as Salafis, but their trend was never different from what later surfaced as the concept of Salafiyyah. (Abbasi 2002: 10). During the time of Prophet Muhammad and the reign of his companions, there was no need to claim Salafiyyah because all the adherents of Islam were steadfast on the clear teachings of Prophet Muhammad and the Ummah was uniform on a universal trend (Abbasi 2002).

The account of the historical development of Salafiyyah is given by Professor 'Imarah (2011). According to him, Salafiyyah has passed through three stages with different features. He argued that the concept as it is, emerged during the Abbasid era (Second Century of Islam) as an ultra- 
conservative and literalist trend attacking the new evolving renaissance of Greek Philosophy in the Muslim community. The then Muslim Philosophers were notorious for rejecting the sacred texts and relying on Greek based philosophy and this forced the emergence of another trend which negated the value of reason and stressed the sacredness of textual literalism. The new trend was headed by Imam Ahmad bin Hanbali (d. 855CE) and supported by the Muhaddithun (Scholars of Prophetic Tradition) namely: Ibn Rahawayih (d. 852CE), Bukhari (d. 870CE), Muslim (875CE), Abu Daud (d. 888CE), Darimi (d. 893CE), Tabarani (d. 971CE) and Bayhaqi (d. 1066CE). Salafiyyah in this stage was characterized by literalism, conservatism and hostility to reasoning. During the time of Ibn Taymiyyah, rationalism was injected to Salafiyyah in the sense that he unequivocally declared that what is reasonable to a common sense will never be contradicted by authentic textual provision; he also asserted that human reason has the natural capacity to discover what is legally normal and abnormal and he also admitted that sound analogical judgement is among the parameters of divine justice. In this stage, Salafiyyah is characterized by the combination of textual provisions with sound reasonings, intellectual disposition and academic polemics. The last stage passed through by Salafiyyah, according to 'Imarah (2011), was quite influenced by the bedouinism and harshness of the Arabian gulf from where the Salafi reformist, Ibn 'Abdil Wahhab, came.

Although, it is indisputably admitted that of those achievements of Ibn Abdil Wahhab are the expulsion of polytheistic acts being practiced by the then Muslims, and minimizing the superstitious doctrines of the mystics, much confusion has been caused in the Muslim Ummah through the current Salafiyyah reducal of challenges facing the Muslims to literal textual provisions and hostility to intellectual reasonings and modernity. Having noticed the difference in the rationalistic version of Ibn Taymiyyah Salafiyyah and the literalistic version of Wahabi - Salafiyyah, Muhammad 'Abduh (d. 1905CE) has advocated in the beginnings of last century for the adoption of rationalistic version of Salafiyyah which connotes the conception of Islam according to the patterns followed by the Salaf and return to the primary sources of Islam.

We are convinced with the analysis of Professor 'Imarah in his account of unifying features in the stages of Salafiyyah, and the characteristic features in each stage. We however differ with 'Imarah in his failure to connect the emergence of Salafiyyah in the second century of Islam to the orthodox Muslims in the preceding century namely: The Companions and their followers. This is because during the uproar that ensued among the Muhaddithun headed by Imam Ahmad and the Greek Muslim Philosophers, the former was known to be defending the status quo, which is the methodology handled down to them from the Sahabah generation, while the latter never claimed to be with the orthodox. Hence, it is convincing that the chain of Salafiyyah started from the Companions, developed by the early Muhaddithun in the second and third centuries, revived by Ibn Taymiyyah and his students, and finally revitalized by Ibn Adul Wahhab through whom it gains acceptance and popularity in current time. It is however worthy of mention that due to the various stages through which Salafiyyah passed, and consequent upon the features with which each stage is characterized, there are currently various factions of Salafiyyah in the Muslim world. Some are inclined to rationalistic version of Salafiyyah as represented by Muhammad Abduh and his student, Rashid Rida, while some are inclined to literalistic version as being represented by the scholars of Saudi conservative Salafiyyah ('Imarah 2011).

Summarily, Salafiyyah is the continuation of the methodology of the Companions and those who followed them. It has passed through various stages with each stage having its mark and feature on the face of Salafiyyah. 


\section{The Emergence of Muslim Brotherhood in Egypt}

Prior to the creation of Muslim Brotherhood in 1928, the Muslim world in general, and Egypt, in particular, were in a mournful state that called for urgent address. Generally, the whole Muslim territories except Saudi, Yemen and Najd, were under the colony of the west which replaced Islamic values with her own world views in philosophical, moral, social, political, economic and educational aspect (Qardawi 1999: 13). This was followed by the unprecedented tribulation in the fall of Caliphasy which then served as the only umbrella for the Muslim unity. The Muslims throughout the globe wept over the fall and various conferences aimed at strategizing ways of reclaiming the lost glory were held. The Muslims had not overcome the trauma experienced in the fall of Caliphasy when the Ummah was visited with another tribulation manifested in the rise of Israel state in the Muslims' domain of Palestine. Now, there was no leadership that would speak for the Ummah and that would assume the forefront role in the ensuing battle. The aforementioned was the general status of the Muslim world. Coming back to Egypt which is one of the most ancient Muslim cities that have had contact with Islam in the Islamic first century during the reign of Umar bn al-Khattab (d. 644C.E), the story is more mournful. The most ancient Islamic institution, Al-Azhar, was too obsessed by internal problems that made her weak in the face of overlapping challenges confronting the Muslims of Egypt. The then constituent authority had inherited from the colonial era policies aimed at barring the institution from having influence on the lives of citizens. Hence, there was no in Al-Azhar the muchneeded solution to the problems of the Ummah as Al-Azhar also staunchly was in need of messiah. The dominating Sufi groups in Egypt were not qualified to rescue the Muslims, as they had constrained Islam to mere supplication and spiritual incantation. The orbit around which the major misfortune of the Egyptian Muslims revolved was the British occupation. The history of the British occupation in Egypt started in 1882 CE. (Yusuf 2009: 53). For thirty years after that, Britain's position was not clearly defined. All that was known was that the mantle of authority was handed over to Egyptian Army under the British Command. People, therefore, had no other choice than to form political associations to serve as pressure groups that would eventually see to the emancipation of Egypt. The agitation gave birth to 1919 revolution of Egypt. It is worthy of note that after the acclaimed independence of Egypt, the British still controlled the political, economic and social direction of the country. Hassan al-Banna (2011: 46), who was a young boy during the manifestation of the aforementioned scenes provides an eye-witness account of the gravity of misfortunes brought by the British occupation to the country:

After the previous world war (1914-1918) and which was the period I stayed in Cairo, the wave of secularism had gotten deep the guise of intellectual liberalism and personal liberty. The wave of irreligiosity and permissiveness had been intensified that they were irresistible. A form tagged intellectual forum was created in manakh street. Lectures and talks which were attacking ancient religions, were being delivered and their speakers were mixture of Muslims, Jews and Christians. Then, books journals and magazines were released to propagate the aforementioned trends which aimed at weakening the influence of religion or even at bringing it to end so that the citizenry would enjoy the true intellectual liberalism they advocated for.

Although, not only Egypt was victim of British westernization, unlike other countries where westernization only affected their ruling or civilized class, Egypt shared the same encounter with Turkey in the sense that westernization drove out Islam entirely from the socio-political terrains and confirmed the Islamic thought to Mosques and religious gatherings. 
Being a student in Darul 'Ulum, an affiliate of Al-Azhar University, and uncomfortable with the current scene, Hasan al- Banna thought that disseminating the teachings of Islam could not continue to be restricted to only mosques. Hence, he converged some of his mates for the task of disseminating Islam through the channels of mosques, coffee restaurants and public gatherings. (p.67). Among those who positively responded were Ustadh Muhammad Madkur, Ustadh Ahmad AbdulHamid, Shaykh Hamid 'Askariyyah and others (Al-Banna 2011: 68). Having noticed that the citizens of Egypt had been polarized into two formidable camps namely: the westernized liberals and the Islamists, with the former having clear-cut upper-hand above the latter, Al-Banna thought that individual efforts were too weak to tackle the wave of westernization, hence the resort to put the onus of leading the Islamist camp on the shoulders of big scholars who through the suggested collaboration with one another could mount the battles horse against the camp of the liberalists who had then constituted the largest populace of the country. He approached Shaykh Yusuf Ad-Dajawi for that assignment. The Shaykh apart from being a reputable Sufi scholar in Egypt, also commanded much respect from the scholars and bigwigs of the Islamic camp in the country (Al-Banna 2011: 85). The Shaykh also showed his sympathy over the state of Egyptian Muslims but gave excuse to AlBanna that the challenge had defied solution as Al-Azhar which remained the largest institution had failed in carrying out the task brought by the latter. After much deliberation and debate over the matter between Al-Banna and the disciples of Ad-Dajawi who later accused the former of un-ethical attitude through his much persistence on convincing the Shaykh, Al-Banna invoked the following historical admonition to Ad-Dajawi and his disciples (Al-Banna 2011: 73):

My boss, terrible war is being waged against Islam to this extent and its warriors, defenders and Muslim scholars are deeprootedly passing their time in enjoyment. Do you think that Allah will not hold you responsible for that you commit? If you know for Islam, scholars and defenders other than you, then direct me to them, perhaps I may find in them what you lack?

Shaykh Dajawi burst into weeping on hearing the foregoing admonition from a young boy in his twenty and sadly asked Al-Banna of what to do. Hassan Al-Banna replied that the task is simple as just to compile the list of Zealot Muslims spread across the scholars and wealthy to collaborate in publishing a weekly newspaper that would be countering that of the liberalists and to form a group that would be made up of dedicated Muslim youths. The suggestion gave birth to Jam'iyyat ashShubban al-Muslimin (Muslim Youths' Society) which had as members notable scholars such as: Rashīd Rida, Muhammad Khidr Husayn, 'Abdul-Aziz Jawish, AbdulWahhab an-Najjar, Muhibbudeen Khatib and host of others. It should be noted that Al-Banna was doing all these as a final year student in Darul 'Ulum. On completing his study, he was posted by the government to 'Isma'iliyyah a village in Egypt, as a primary school teacher. Al-Banna relocated to Isma'iliyyah with his high ambition to provide a formidable response to the current problem of the Ummah. It took him half of a year to keenly observe the determinants of influence in that vicinity and he discovered that the major channels of influencing the populace are four namely: the Muslim scholars, the leaders of Sufi groups, the figure personalities and places of assembly. (p.84). He decided to go for the fourth one as he had confirmed its effectiveness in Dawah when he was staying in Cairo. Al-Banna raised followers and adherents in the assembly of workers, artists and common people and in March, 1928 was visited by six of those who had been influenced by his sermons namely: Hafith 'AbdulHamid, Ahmad Al-Husuri, Fuad Ibrahim, 'Abdur-Rahman Hasbullah, 'Isma'il 'Izzu and Zakariyya al-Maghribi, purposely to take off an organization that would reclaim the lost glory of Islam and they all gave their allegiance (Bay'ah) to Hassan Al-Banna. The event marks the beginning of Muslim Brotherhood in current time. 
It is worthy of stress that the circumstances that provoked the establishment of the group are not only cumbersome, they constituted the biggest challenges confronting the Muslims. Hence, the group was to assume the responsibility of repositioning the Muslims in Egypt and in the global world. It is appealing that the personality that would bear the flag of this most needed organization at that time was just of twenty-two years. This alludes to the dual facts that the then aged scholars had been incapacitated by the overlapping challenges that required the address of an extra ordinary reformer; and also indicates that with his little age at that time coupled with the attempt he made at rising to the responsibility that should had been assumed by Al-Azhar which stood out as the reference point for the Ummah, Hassan al-Banna stands out as one of the most important figures and reformers in the current history of Islam. It is however debatable if with the little age and experience, Hassan alBanna could successfully surmount the outlined challenges of the Ummah or alternatively add to their gravity. This can only be settled through open-minded and objective research and investigation into the objectives, methodology and impacts of the Jama'ah.

\section{Theological Polemics between the Salafiyyah and Muslim Brotherhood}

Theology is translated as the study of religion and belief or a set of religious beliefs (Oxford 2002). The technical word for Islamic theology is Usul ad-Dīn, At-Tawhïd and Aqĩdah (Muhzali 2005: 45). In Islam, theology is placed at esteemed position for it is not only considered the foundation upon which other ritual activities are built, it also defines the ideological identity of a Muslim (Bakru 2011: 282). It is note- worthy that theological matters are responsible for the upsurge and influx of sects in the religion of Islam. Hence, what is being referred to as Islamic theology today is an expression of polemics that border around the creeds and doctrines in Islam (Arikewuyo 2015: 43). It is however instructive to stress that as far as the Muslim theologians are concerned, there are only two theological blocs in Islam namely: The Ahl as-Sunnal Wal Jama'ah (People of Tradition and Cohesiveness) and the Ahl al-Hawa wal Bidcah (People of whims and heresies) (Muhzali 2005: 14). The first bloc is constituted by the Muhaddithun, Ashacirah and Maturidiyyah, who all represented the exact theological school of Islam being held by the first generation of Muslims before the emergence of dissenting theological schools immediately after the death of Uthman bn Affan (d. 656CE). The second bloc is constituted by various heretic schools such as the Mu'tazilah, Murji'ah, Jahmiyyah, Shiah, Qadariyyah, Jabariyyah and Khawarij. The characteristic feature of the former bloc is that all its constituents have common notion and view regarding the areas where the various constituents of second bloc differed and in addition to this, unlike the latter, they never declared one another as disbelievers because of little differences in some equivocal matters of theology. Although some classical Muhaddithun have rejected the Asha irah and Maturidiyyah from the first bloc owing to the adoption by the latter of philosophical weapon to defend the orthodox creeds, which was described as antithetical to the path of first generation of Muslims, Ibn Taymiyyah has maintained that despite the foregoing accusation, Ashacirah and Maturidiyyah are very proximate to Ahl as-Sunnah (Arikewuyo 2015: 48).

Based on the above preface, the current Salafiyyah groups are sheer adherents of the orthodox theological school as represented by the second and third classical works of the Muhaddithun. In the same direction, the Muslim Brotherhood, as manifested by the claims of its founder and leading scholars, also toes the line of Salafiyyah in theological matters. This can be proven in the following assertion: the current Salafiyyah groups, with their various inclinations, give revered attention to theology and creeds and this is often displayed through the regular theme of their awareness lectures and through the number of works published on the aspect by Salafi scholars in current time. The Muslim Brotherhood's scholars have also showed serious concern for the matters of creeds through their various works on that aspect. The following scholars of the group

https://doi.org/10.24035/ijit.15.2019.002 
have all published books on Aqidah: Hasan al-Banna (Kitab al-Aqaid); Muhammad al-Ghazali ("Aqidat al-Muslim); Sayyid Sabiq (Al-'Aqaid al-Islamiyyah), Sayyid Qutb (Khasais at-Tasawwur al-Islami), 'Umar Ashqar (Al-Aqidah fi Allah); Yusuf Qardawi (Haqiqat at-Tawhid); `Abdul Majid Ziydani (Binau al-'Iman); Muhammad Na'im Yasin (Al-'Iman); and Abdullah Nasih 'Alawan (Ilm at-Tawhid) (Shahatah 2012: 34).

The major themes that attract much condemnation in the theological thought of Salafiyyah are veneration and supplication to the graves; amulets, incantation, fortune telling and calling other than Allah. The aforementioned themes constitute what the current Salafiyyah groups referred to as Tawhid al-Uluhiyyah (monotheism of divineship) (Ibn 'AbdilWahhab 1420). The works of Muhammad bn 'Abdul Wahhab who is regarded as the father of current Salafiyyah are replete with focus on Uluhiyyah. The founder of the Ikhwan has displayed conformity to Salafiyyah when he included the aforementioned themes in the set of orientation that all bonifide members of his Jama'ah must imbibe. He asserted thus:

$$
\text { والتمائم والرقى والودع والرمل والمعرفة والكهانة وادعاء الغيب وكل ما كان من هذا الباب منكر تجب محاربته، إلا }
$$

Amulets, (demonic) incantations, fortune-telling with the means of cowry, sand and other forms of alleging (the knowledge) of the unseen; and all what fall in this aspect are condemnable acts against which war should be waged save (those that are composed) from a Qur'anic verse or traditionally accepted incantation (Ibn 'Abdil Wahhab 1998: 251).

In the same direction, he also stresses that:

$$
\begin{aligned}
& \text { وزيارة القبور أيا كانت سنة مشروعة بالكيفية المأثورة، ولكن الاستعانة بالمقبورين أيا كانوا ونداءهم لذلك وطلب } \\
& \text { قضاء الحاجات منهم عن قرب أو بعد والنذر لهم وتشييد القبور وسترها وإضاءةا والتمسح بها، والحلف بغير الله } \\
& \text { وما يلحق بذلك من المبتدعات كبائر تحب محاربتها، ولا نتأول لهذه الأعمال سدا للذريعة. }
\end{aligned}
$$

Visitation of the commentaries is allowed in any form provided it is done in the traditionally transmitted way. But seeking the (divine) help from those in the graves no matter high (they may be placed); supplicating to them; beseeching their assistance in fulfilling one's pursuit, giving covenant to them; beautification of graves with light and shelter, seeking blessing through them; taking oath with other than Allah and all other parallel heresies are grave sins against which war should be waged and we should not engage in (tactical) interpretation of the (aforementioned) so that the door to evil could be closed (Ibn 'Abdil Wahhab 1998: 253).

Professor Tawfiq Yusuf (2005) has carried out a comparative study of the themes of Kitab atTawhid by Ibn 'Abdil Wahhab and the themes of Tawhid in the literature of Hasan al-Banna and he concluded that the two aforementioned quotations of the latter on the discourse have covered the contents of twenty-five chapters in the work of the former. Hence, what the current Salafiyyah groups advocate for regarding the reformation of the creeds is well spelt out in the literatures of Muslim Brotherhood. It is however disturbing to observe that many scholars of current Salafiyyah have often 
accused the Ikhwan of lackadaisical attitudes towards ${ }^{c}$ Aqidah despite the assertion of the foregoing (Al-Hashidi 2002: 17).

It is instructive to mention that despite the conformity of the Ikhwan to the Salafiyyah in some matters of creeds, there are aspects which constitute bone of contention among the duo in the theological methodology. The first major discrepancy is the degree of priority attached to Tawhid (monotheism) by each of the two groups. According to the Salafiyyah school, the paramount problem of current Muslims is deterioration in monotheistic ideology of Islam and this is responsible for the reason why the Muslims of nowadays are described as similitude of the non-believers of Makkah. Infact Ibn Abdil Wahhab is of the opinion that the Makkan pagans were even better than some current Muslims in the sense that the former often directed supplication to Allah in the state of tribulation while the latter recourse to other than Allah while in tribulation (Ibn 'Abdil Wahhab 2012: 15). This exaggerated description of the current Muslims is behind the reason why the Salafiyyah groups have focused, in emulation of the prophetic pattern at Makkan stage, exclusively on preaching Islamic monotheism. Although, it is not pronounced that the current Muslims have become pagans, the current Salafiyyah groups painstakingly address the current Muslims the way Prophet Muhammad addressed the Makkan pagans in the premier stage of his mission. Contrary to this, the Ikhwan believe that current Muslims are not likened to the pagans but admit that there are theological flaws that need to be corrected (Yusuf 2005: 136). They argued that such flaws are not different from that committed by the Companions after embracing Islam and they did not cease to be Muslims. A good example of this phenomenon is witnessed when the Prophet was leading his companions to the Battle of Hunayn. They passed through a tree being worshipped by the pagans and some Companions suggested that the Prophet should also assign a tree to be adorned by the Muslims in emulation of the pagans. The Prophet only castigated them and they all moved on to the battle field without declaring them to have committed disbelief (Tirmidhi 2004: no.2180). Hence, based on this argument, the Ikhwan do not give exclusive focus on reforming the creeds of the Muslims at the expense of other aspects of Islam.

Another bone of contention between the two schools regarding theological matters is that theology according to the Salafiyyah groups contains the creeds taught by the Prophet and most especially the polemics of early Muhaddithun in refuting the theological heresies of Muslim sects which are identically today not existing (Yusuf 2005). Hence, perusing that kind of theology necessarily gives one the theological exposure often more than theological training. The Ikhwan believe that the sake for which theology is taught in Islam is to imbibe in the Muslims spiritual strength and certainty and that can be achieved by focusing on the direct instructions provided in the Quran and Sunnah, paying less attention to the polemics over which subjects are in termination (Yusuf 2005). The foregoing explains why theology is fast becoming source of polemics and division than of spiritual fortification to the current youths of Salafiyyah groups. There are matters in Islamic theology that have nothing to do with personal piety than with polemics over the description of equivocal creeds. Such matters from ancient time have constituted cause of disunity, grudge and hullaballo among the Muslim scholars. The Ikhwan seek to put end to the un-necessary skirmishes in the face of bigger tribulations that need the co-operation of all Muslims to withstand them. An example of such matters is polemics over the anthropomorphic status of Allah. After navigating into the unending polemics over the matter and asserting the contention among the Muslim ancestors (Salaf) who believed literarily that Allah possesses anthropomorphic attributes and the successors (Khalaf) who maintained that though anthropomorphic words are evident in the attributes of Allah, but they should be interpreted metaphorically, Al-Banna concludes that although he is convinced with the argument of the Salaf, such matter that has no bearing on personal piety should not be allowed to break the cohesion of the Muslims as the terrain of Islam is wide (Al-Banna 1998: 204). This submission has subjected the founder of Muslim Brotherhood to the attacks and castigation of 
current Salafi scholars who insisted that the Asha'irah and Maturidiyyah scholars despite being the largest proportion of Muslim scholars in all Islamic disciplines should be declared as heretics (AlHashidi 2002: 41). When asked about the Asha'irah and Maturidiyyah, Ibn Uthaymin who is one of the most influential scholars of current Salafiyyah ruled out the duo from the camp of Ahl as-Sunnah wal Jamacah (Ibn Uthaymin 1424). It is worthy of note that the insistence of the current Salafiyyah groups on condemning the way of Asha'irah is in the spirit of perpetuating the protracted enmity that existed between the Hanabilah and the Asha'irah. Al-Banna intends to break the dichotomy of Hanbali -Ashcari hostility by directing attention to area of agreement among the hostile trends which is the belief in the un-resemblance of Allah to His creatures and the uniform faith in His noble attributes. It is believed Al-Banna was fired by the zeal of addressing bigger issues confronting the Muslim Ummah at the expense of elements of division among the equivocal matters of theology.

Another aspect in theology that is tearing Muslims apart which the Muslim Brotherhood intends to terminate is Tawassul (intercession) with Prophet Muhammad and the saints. Al-Banna argues that Tawassul is different from the unanimously condemned Istigathah (seeking the help of other than Allah) in the sense that in the latter the supplicator has replaced Allah with others, while in the former he recognized the identity of God to which supplication is directed from the creature with whose dignity is used as intercession between him and God (Al-Banna 1998). Hence, according to him, the polemics over the permissibility of Tawassul is not theological, rather it is juristic. (p.306). Current Salafi scholars have condemned Al-Banna and Muslim Brotherhood for laxity in the case of intercession (Al-Hashidi 2002: 43). They supported their argument for the prohibition of intercession with a hadith wherein the Prophet was reported saying: "Supplication is the real ritual dedication" (Tirmidhi 2004: no.3371). Their interpretation of the hadith is that since supplication as reported is considered act of 'Ibadah (ritual), it is not allowed to invent new way of doing it (AlHashidi 2002). I submit that the quoted hadith is not applicable to the issue at hand for the protagonists of intercession also have evidence in the hadith of Uthman bn Hanif wherein the Prophet permitted him to intercede with him (Tirmidhi 2004: no.2113). Although, the antagonists of intercession have interpreted the same hadith to connote the permissibility of interceding with the direct supplication of Prophet Muhammad on behalf of the real supplicator, the denotation of the hadith remains speculative. It is worthy of note that many students of Al-Banna have joined the race of the polemics over intercession. Qardawi (1999) submits that Al-Banna's conclusion that intercession is of juristic matters has been corroborated by the same submission given by Ibn 'Abdil Wahhab and Albani, who are of current Salafiyyah. He also adds that what actually justifies the submission is the surface of the discourse in virtually all the various works on Islamic jurisprudence cut across all the schools of thought and that the dust raised by the matter even among the ancient Sunni scholars could not be glossed over (p.320). Jasim Yasin (1990), other scholars of Muslim Brotherhood, argues that even if the case is admitted to be of theological, it does not belong to fundamental aspects of theology (Usul) for the Companion of Prophet often disagreed over the branches (Furu') of theology. It is worthy of mentioning that Al-Banna including many of the Brotherhood's scholars detest intercession, but they also recognized the stance of other scholars over the matter.

From the fore-going elaboration, it appears that both the Muslim Brotherhood and Salafiyyah groups represent the traditional orthodox Muslims in fundamental creeds of Islam. In addition, the esteemed position at which Islam places creeds and theology has received the pleasure of the two groups through the scholarly contribution given to it by them.

It is however pertinent to note that unlike the Muslim Brotherhood, the current Salafiyyah has reduced the problem of the Ummah exclusively to creedal defects. Hence, the group exerts all its strength on reforming the faulty creeds of Muslims at the expense of other seeming problems. The Muslim Brotherhood discovers that the problem militating against the progress of current Muslims 
is all encompassing and comprehensive. Hence, there is ardent need of overhaul and comprehensive revivalism. Faulty creeds are just an archetypical epitome of Muslims deterioration, according to the Ikhwan.

The inherited polemics contained in the theological literature of the orthodox Muslims in the second and third centuries are the basic themes of Islamic creeds to the current Salafiyyah group. It is worthy of note that the basic contents of the afore-mentioned literature are refutations against the then heretic sects. Hence, theological matters are fast becoming source of dispute, grudge and academic polemics to the Salafiyyah adherents other than inspiration for spiritual contentment and certainty. The Muslim Brotherhood adopts the prophetic methodology and that of his Companion before the emergence of theological sects. The methodology is based on personal conviction and spiritual certainty as the goals for theological explanation. It is therefore accurate to describe the methodology of Salafiyyah in this discourse as theological polemics and that of the Ikhwan as theological training.

Arising from the above assertion, we recommend that in view of the mournful status of Muslims creeds in current time, the Salafiyyah group should focus on the course of uplifting the spiritual backwardness of large proportion of Muslims through the means of giving much concern to fundamental creeds that have bearing on the personal piety, rather than lavishing strength on equivocal and controversial matters of creeds. This will certainly change the story of theological discourse being a source of mutual grudge and incrimination to be a factor for spiritual upliftment, cohesion and unity among the current Muslims.

\section{References}

Abbasi, I. 2002. Ad-Da'wat al-Salafiyyah wa Mawqifuha min al-Harakat al-Ukhra. Cairo: Dar al-Iman. Al-Banna, H. 1998. Majmuat Rasail al-Imam. Alexandria: Dar al-Da'wah.

Al-Banna, H. 2011. Mudhakkirat al-Da'wah wa al- Da'iyah. Cairo: Dar al-Sahwah.

Al-Hashidi, F. 2002. Risalatun Ukhawiyyah. Yemen: Dar al-Athar.

Arikewuyo, N. A. 2015. Al-Ghazali in selected works of Ibn Taymiyyah. Ilorin: M.A. Thesis, Department of Religions, University of Ilorin.

Bakru, A. 2011. Malamihun Raisiyyah li al-Manhaj al-Salafi. Cairo: Maktabat Fayyad.

Bakru, A. 2012. Muhadaratun fi al-Salafiyyah. Cairo: Dar Ibn al-Jawzi.

Bukhari, M. I. 2007. Sahih al-Bukhari. Cairo: Dar Ibn al-Haytham.

Hilali, S. 2013. Limadha Ikhtartu al-Manhaj al-Salafi. Cairo: Maktabat al-Hady an-Nabawi.

Ibn 'Abdil Wahhab, M. 2012. Al-Qawa'id al-'Arba'. Cairo: Maktab al-Hadyi Muhammadi.

Ibn 'AbdilWahhab, A. 1420H. Fath al-Majd. Riyadh: Dar Ibn Al-Athir.

Ibn Manzur, M. 2007. Lisan al- 'Arab. Cairo: Darul Ma'arif.

Ibn Taymiyyah, A. 2006. Majmuat al-Fatawa. Cairo: Darul Hadith.

Ibn 'Uthaymin, M. 1424H. Sharh al-'Aqidat al- Islamiyyah. Cairo: Dar Ibn al-Jawzi.

'Imarah, M. 2011. Al-Salaf wa al-Salafiyyah. Cairo: Maktabat Wahbah.

Muhzali, M. 2005. Muqaddimat fi al-'Aqidat al-Islamiyyah wa 'Ilm al-Kalam. Cairo: Dar al-Hadith.

Muslim, H. 2008. Sahih Muslim. Cairo: Dar ibn al-Haytham.

Qardawi, Y. 1999. Al-Ikhwan al-Muslimun. Cairo: Maktabah Wahbah.

Shahatah, M. S. n.d. Al-Wajh al-Salafi 'inda al-Ikhwan al-Muslimin. n.l. Maktabat Shamilah.

Tirmidhi, I. 2004. Sunan Tirmidhi. Cairo: Dar Ibn al-Haytham.

Yusuf, B. 2009. Sayyid Qutb: A Study of His Tafsir. Kuala Lumpur: Islamic Book Trust.

Yusuf, T. 2005. Al-Ikhwan al-Muslimun. Mansurah: Al-Shuruq.

https://doi.org/10.24035/ijit.15.2019.002 